\title{
REVIEW
}

\section{Parasitic fungi of phytoplankton: ecological roles and implications for microbial food webs}

\author{
Serena Rasconi, Marlène Jobard, Télesphore Sime-Ngando* \\ LMGE, Laboratoire Microorganismes: Génome \& Environnement, UMR CNRS 6023, Clermont Université, \\ Blaise Pascal, Clermont-Ferrand II, 63177 Aubière Cedex, France
}

\begin{abstract}
Microbial parasites typically are characterized by their small size, short generation time, and high rates of reproduction, with a simple life cycle occurring generally within a single host. They are diverse and ubiquitous in aquatic ecosystems, comprising viruses, prokaryotes, and eukaryotes. Recently, environmental 18S rDNA surveys of microbial eukaryotes have unveiled major infecting agents in pelagic systems, consisting primarily of chytrids (Chytridiomycota). Chytrids are external eucarpic parasites that infect diverse prokaryotic and eukaryotic algae, primarily diatoms and filamentous species. They produce specialized rhizoidal systems within host cells, i.e. the nutrient conveying system for the formation of fruit bodies (sporangia) from which propagules (motile uniflagellated zoospores) are released into the environment. In this review, we summarize the ecological potential of parasites of phytoplankton and infer the implications for food web dynamics. We focus on chytrids, together with other parasitic eukaryotes, with special emphasis on (1) the role of microparasites in driving the structure of phytoplankton communities, (2) the role of chytrid zoospores in matter and energy transfer, and (3) the potential consequences of infections for food web dynamics. We raise the question of genetic potential from host-parasite interactions and also of how environmental factors might affect the host-parasite relationships in the pelagic realm.
\end{abstract}

KEY WORDS: Fungi $\cdot$ Chytrids $\cdot$ Microbial parasites $\cdot$ Phytoplankton $\cdot$ Microbial ecology $\cdot$ Food webs Aquatic ecosystems

Resale or republication not permitted without written consent of the publisher

\section{INTRODUCTION}

Parasitism is one of the earlier known and most common ecological interactions in nature (Cavalier-Smith 1993), occurring in almost all environments (Lafferty et al. 2006). Parasites have received much more attention in terrestrial ecosystems than in aquatic ecosystems (Kuris et al. 2008), where they represent a strong forcing factor for critical ecological processes, e.g. population dynamics, species succession, competition for resources, species diversification, and energy and gene flows (Hudson et al. 2006). Few attempts have been made to include parasites in the food web dynamics of pelagic systems (McCallum et al. 2004, Amundsen et al. 2009), with special emphasis on parasites of plants (Buschmann et al. 2001), invertebrates (Perkins 1993), and vertebrates (Marcogliese 2004). Recent ecological and molecular surveys in pelagic environments have revealed a high occurrence of eukaryotic putative parasitoids, especially in the picoplanktonic size-fraction (López-García et al. 2001, Lefranc et al. 2005, Lefèvre et al. 2007, 2008), adding to the other typical parasitic biological entities such as viruses (Sime-Ngando \& Colombet 2009). Eukaryotic parasites known from $18 \mathrm{~S}$ rDNA diversity surveys include zoosporic fungi as a major waterborne group, comprising both host-attached vegetative (e.g. sporangia) and free-living infective (e.g. zoospores) stages (Gleason \& Macarthur 2008), thus occupying various niches in the plankton (see Fig. 2). It is likely that these parasitic stages have been misidentified as bacterivorous protists in previous studies (Lefèvre et al. 2007). Fungi exhibit different and more 
diverse trophic strategies (i.e. parasitism, saprotrophy, symbiosis) than phagotrophic protists. Fungal life stages can represent key intermediates in the food chain (Gleason et al. 2009). Indeed, fungal zoospores have suitable dimensions and represent a valuable food source for zooplankton (Kagami et al. 2007a,b). Furthermore, similar to some protists (Desvilettes \& Bec 2009), fungal zoospores contain fatty acids that might upgrade the nutritional quality of food ingested by zooplankton such as Daphnia (Kagami et al. 2007a,b).

It is important to include eukaryotic parasites in the microbial ecology of aquatic environments. In the pelagic realm, microorganisms sustain the food web; therefore it would be valuable to understand the ecological consequences of parasites on community properties. Some authors have investigated the effects of parasitism on the growth of algal species and phytoplankton successions (Van Donk 1989, Ibelings et al. 2004, Kagami et al. 2007b) or on the genetic structure of infected populations (De Bruin et al. 2008). However, few attempts have been made to include parasites in the food web dynamics of aquatic ecosystems (Sigee 2005) and to understand environmental factors that trigger parasitic epidemics (Gleason et al. 2008).

Our goal is not to review the entire literature on parasitism, but instead to draw attention to the as yet ignored ecological potential from the diversity and functional roles of microbial parasites in the pelagic community. We believe that this is timely, will help to integrate 'novel' ecological perspectives, and extend the concept of parasitism and their functional potential to pelagic microbial food webs. Our review is the first in which theoretical concepts from the study of animals' parasites are applied to aquatic microbes. We focus primarily on chytrids and other parasitic eukaryotes and extend the concept of parasitism and the related functional potential not only to primary producers but also to the entire microbial food web. Specifically, by using available knowledge on chytrid infection of phytoplankton, we investigate (1) the role of microparasites in driving the structure of plankton communities, (2) the role of chytrid zoospores in matter and energy transfer, and (3) the potential consequences of fungal infections for food web dynamics. We raise the question of genetic potential from host-parasite interactions and also of how environmental stress might affect the host-parasite relationships.

\section{OVERVIEW OF THE DIVERSITY OF ENVIRONMENTAL MICROPARASITES}

In natural environments, parasites include a broad variety of organisms, including both plants and animals, encompassing a great diversity of life forms
(Ricklefs \& Miller 1999, Poulin \& Morand 2004). In aquatic ecosystems, parasitism involves viruses, bacteria, protozoans, fungi, helminths, and arthropods. Larger parasites, i.e. helminths and arthropods, usually are transmitted via one or more intermediate hosts and are defined as macroparasites (Anderson \& May 1979). In this review, we focus on microparasites (Table 1), typically characterized by their small size, short generation time, and high reproductive rates (Anderson \& May 1979, 1981, May \& Anderson 1979, Lafferty \& Kuris 2002). They are often called pathogens and are also generally characterized by a simple life cycle, generally completed within a single host. This offers a good model for the study of host-parasite interactions in natural ecosystems.

The most diverse and abundant microparasites in nature are viruses, which infect almost all types of cellular organisms (Sime-Ngando \& Colombet 2009). Viruses are the most simple forms of known life, consisting essentially of genetic material (DNA or RNA) covered with a protein coat. Even though the debate on whether viruses are living organisms remains open (Moreira \& López-García 2009), there is no doubt that they are obligate parasites, unable to replicate outside their host cells. There are about $10^{31}$ viral particles in the biosphere, most of which are aquatic (Rohwer \& Edwards 2002). They represent the largest reservoir of uncharacterized biological diversity on the earth, with abundances typically ranging between $10^{4}$ and $10^{8}$ particles $\mathrm{ml}^{-1}$ in natural waters. Phages, primarily bacteriophages, predominate and are responsible for about $10^{23}$ infection events per second, producing between $10^{8}$ and $10^{9}$ tonnes of dissolved carbon in the open oceans (Suttle 2007). This activity is significant in structuring microbial communities and in the related biogeochemical cycling (Fuhrman 1999, Wommack \& Colwell 2000). In addition, viruses share a long coevolutionary history with their cellular hosts. They play an important role in the evolution of key cellular genes (e.g. DNA polymerases, helicases; Comeau \& Krisch 2005) and can even contain typical viral genes capable of coding for essential photosynthetic proteins (Lindell et al. 2005). Phages are perhaps the most studied microparasites in the plankton, although the first ecological study was published only 2 decades ago (Bergh et al. 1989).

In contrast to viruses, few studies are available on bacterial parasites in aquatic microbial ecology. Disease-causing aquatic bacteria, including many of the genera Vibrio and Pseudomonas (Fryer \& Rohovec 1993), are especially well studied in marine finfish aquaculture (Fryer \& Sanders 1981, Meyer 1991). Parasitic bacteria have also been reported from planktonic crustaceans, infections being generally harmful by drastically reducing the host's reproductive success 
Table 1. Overview of the occurrence of microparasites in aquatic ecosystems

\begin{tabular}{|c|c|c|c|}
\hline Parasite group (species) & Host & Environment & Source \\
\hline Virus & All organisms & All aquatic systems & Wommack \& Colwell (2000) \\
\hline \multicolumn{4}{|l|}{ Bacteria } \\
\hline Proteobacteria (Vibrio spp.) & Salmonids & Freshwater & Fryer \& Rohovec (1993) \\
\hline Proteobacteria (Pseudomonas spp.) & Salmonids & Freshwater & Fryer \& Rohovec (1993) \\
\hline Firmicutes (Pasteuria ramosa) & Daphnia magna & Freshwater & Schmidt et al. (2008) \\
\hline $\begin{array}{l}\text { Proteobacteria } \\
\text { (Spirobacillus cienkowskii) }\end{array}$ & Daphnia spp. & Freshwater & Ebert (2005) \\
\hline \multicolumn{4}{|l|}{ Alveolata } \\
\hline Apicomplexa (Perkinsus spp.) & Dinoflagellates & Marine and freshwater & $\begin{array}{l}\text { Moreira \& López-García (2003) } \\
\text { Lefranc et al. (2005) }\end{array}$ \\
\hline Ciliophora & Fishes & Artificial ponds & Knopf et al. (2007) \\
\hline Ciliophora (Trichodina sp.) & Copepods & Reservoir & Da Silva et al. (2009) \\
\hline Ciliophora (Apionsoma sp.) & Fishes & Freshwater & Li et al. (2008) \\
\hline $\begin{array}{l}\text { Dinoflagellata } \\
\text { (Amoebophyra spp.) }\end{array}$ & $\begin{array}{l}\text { Photosynthetic } \\
\text { dinoflagellates }\end{array}$ & Marine & $\begin{array}{l}\text { Guillou et al. (2008), } \\
\text { Chambouvet et al. (2008) }\end{array}$ \\
\hline \multicolumn{4}{|l|}{ Stramenopiles } \\
\hline Oomycota & $\begin{array}{l}\text { Brown algae } \\
\text { and diatoms }\end{array}$ & Marine & $\begin{array}{l}\text { Schnepf et al. (1978) } \\
\text { Gachon et al. (2009) }\end{array}$ \\
\hline Oomycota & Daphnia spp. & Freshwater & Ebert (2005) \\
\hline \multicolumn{4}{|l|}{ Fungi } \\
\hline Microsporidia & Crayfish, crustacean & Marine and freshwater & $\begin{array}{l}\text { France \& Graham (1985), } \\
\text { Vávra et al. (2005) }\end{array}$ \\
\hline Ascomycota & Daphnia spp. & Freshwater & Ebert (2005) \\
\hline Chytridiomycota & Daphnia spp. & Freshwater & Johnson et al. (2009) \\
\hline Chytridiomycota & Phytoplankton & Freshwater & Canter (1950a), Sparrow (1960) \\
\hline
\end{tabular}

(Ebert 2005). In natural conditions, high prevalence of infection was found in ponds (Mitchell et al. 2004), and the growth of some bacterial microparasites (e.g. Pasteuria ramosa) seems to be influenced by water temperature (Green 1974).

Parasitic protists in aquatic environments primarily include members of the Alveolata and stramenopiles. Alveolata are one of the major groups of eukaryotes in marine and estuarine ecosystems (Coats et al. 1996), comprising the divisions Apicomplexa, Ciliophora, and Dinoflagellata, all of which contain parasites. Apicomplexa species are all known as obligate parasites, and the most abundant are in the order Perkinsida, which have been identified in both marine and freshwater microeukaryote phylogenies (Moreira \& López-García 2003, Lefranc et al. 2005). Parasitic Ciliophora contain the genera Trichodina and Apiosoma, which are common in both freshwater and marine environments, where they live attached to a variety of aquatic animals (Li et al. 2008, Xu \& Song 2008, Da Silva et al. 2009). Dinoflagellates form a heterogeneous group of organisms with a wide variety of trophic strategies. Parasites are mostly represented by Syndiniales, which is a dinoflagellate order exclusively composed of marine specimens (Guillou et al. 2008). Stramenopiles are also a diversified and important group of protists in pelagic systems, containing key ecological species such as photosynthetic diatoms or bacterivorous bicosoecids
(Moon-van der Staay et al. 2001). Parasites are mostly found in the phylum Oomycota, also called fungus-like organisms due to their lifestyle and infection strategies, which are similar to those of true fungi (Latijnhouwers et al. 2003). They mostly infect brown algae (Sekimoto et al. 2008) and diatoms (Schnepf et al. 1978) in a wide variety of marine environments (Raghukumar 1987, West et al. 2006, Gachon et al. 2009). Infections of dinoflagellates by oomycetes also seem to be widespread in marine ecosystems, although primarily caused by Perkinsozoa and other dinoflagellates (Park et al. 2004).

In aquatic ecosystems, true fungi mainly consist of species belonging to the taxonomic group of Dikaryomycota (Basidiomycota and Ascomycota) and function primarily as saprophytes (Wong et al. 1998, Shearer et al. 2007). Their role in detrital processing has not been well studied, although recent reviews provide some evidence that fungal saprobes may play an important role in pelagic ecosystems (Jobard et al. 2010, Wurzbacher et al. 2010). Parasites belong primarily to Microsporidia (France \& Graham 1985, Vávra et al. 2005), Blastocladiomycota (James et al. 2006), and Chytridiomycota, i.e. chytrids (Canter 1950a). Chytrids are considered an early branch of the Eumycota (Barr 1990) and are the sole group that produce motile, flagellated zoospores, characterized by a small size ( 2 to $6 \mu \mathrm{m}$ ) and a single, posterior, whiplash flagellum (Sparrow 1960). The 
presence of these dispersal propagules places chytrids within the polyphyletic group of zoosporic true fungi, which are particularly well adapted to the planktonic lifestyle. Parasitic chytrids infect a wide variety of hosts, including fish, eggs, zooplankton, algae, and other aquatic fungi, but primarily phytoplankton in aquatic systems (Table 1). Diseases on algae are common and have been reported as a recurrent cause of host population decline (Canter \& Lund 1948). Phytoplankton parasites mainly belong to chytridiomycetes and oomycetes, both of which used to be called phycomycetes or 'algal fungi'. The early taxonomy of these organisms is discussed extensively by Sparrow (1960) and, before modern taxonomy (Barr 1990), the number and type of flagella were the basis for separating chytridiomycetes (1 flagella) and oomycetes (2 flagella). In addition, the vegetative and reproductive structures of chytrids (i.e. thallus and sporangium, respectively) are characterized by chitinaceous walls, while oomycetes have cellulosic cell walls and completely lack chitin. In freshwater ecosystems, most studies describe chytrids as widespread parasites of phytoplankton (Canter \& Lund 1948, 1951, 1953). These parasites are external eucarpic parasites that infect various phytoplankton species, primarily diatoms and filamentous species, and produce a special rhizoidal system within host cells, i.e. the nutrient conveying system for the formation of fruit bodies (sporangia) from which propagules (zoospores) are released into the environment. Most fungal parasites have a narrow host range, and some are highly specific to particular host strains (Doggett \& Porter 1995).

\section{PELAGIC SYSTEMS AND EUKARYOTIC MICROPARASITES}

Aquatic environments are more open than terrestrial environments, and parasites are more likely to scatter in the plankton, which offers greater contact rates with hosts. The related ecological potential (i.e. from infection activity) is high, and it is thus worth assessing the impact of parasitism in pelagic food webs. The development of molecular tools has increased our knowledge of both prokaryotic and eukaryotic microbial populations in pelagic ecosystems (Diez et al. 2001, Demergasso et al. 2004), and a large reservoir of eukaryotic parasites was recently unveiled in both marine (Guillou et al. 2008) and freshwater ecosystems (Lefranc et al. 2005, Lefèvre et al. 2007, 2008).

Surveys of environmental 18S rDNA have now established heterotrophic microeukaryotes as a polyphyletic group of highly diverse cellular organisms in the pelagic zone, with more functional and ecological characteristics than previously thought. High abun- dance and diversity were determined among the groups of stramenopiles and alveolates in a wide range of marine environments, including oligotrophic waters of the equatorial Pacific Ocean (Moon-van der Staay et al. 2001), surface and deep Antarctic seawaters (López-García et al. 2001, Moreira \& López-García 2002), and Mediterranean and North Atlantic surface waters (Diez et al. 2001). Many of the retrieved groups appear geographically ubiquitous, with alveolates representing one of the major eukaryotic lineages, consisting of heterogeneous organisms that have adopted different trophic modes. A high diversity in this lineage was found in the orders Perkinsida (Moon-van der Staay et al. 2001) and Syndiniales (mostly in the genus Amoebophrya) (Guillou et al. 2008), most of which are known as obligate parasites (Moon-van der Staay et al. 2001). Recently, perkinsids have been shown to be a major controlling factor for harmful phytoplankton (and their ability to cause toxic red tides), such as the photosynthetic dinoflagellates Heterocapsa rotundata, H. triquetra, Scrippsiella trochoidea, and Alexandrium minutum (Chambouvet et al. 2008). Sequences belonging to fungal-like organisms were also retrieved and related to oomycetes, which are parasites of green and brown algae (Moon-van der Staay et al. 2001, Moreira \& López-García 2002), and to traustrochytrids, which may play a major role as decomposers in marine environments (Raghukumar 2002).

Although largely under-sampled compared to marine systems, similar surveys were conducted in freshwater environments, and the molecular diversity of pelagic heterotrophic eukaryotes has also revealed interesting perspectives. Many groups identified in these surveys appeared unrelated to sequences from marine ecosystems (Lefèvre et al. 2007), suggesting that aspects of eukaryote microbial diversity are specific to certain aquatic environments and that marine and freshwater microbial eukaryotes may be quite different in terms of $18 \mathrm{~S}$ rDNA-based phylotypes. This confirms the recent analysis suggesting that marinefreshwater transitions have been infrequent events during the diversification of microbes, and that most of these transitions occurred long ago in evolutionary terms (Logares et al. 2009). Furthermore, in freshwater lakes, some differences have emerged in relation to the different environmental features of the studied ecosystems. In oligotrophic lakes, fungi generally dominate the discovered diversity, and chytrids represent up to $73 \%$ of the total fungal diversity (Lefèvre et al. 2008). In eutrophic lakes, phylogenetic analyses have highlighted a massive presence of Perkinsida (Lefranc et al. 2005), with a substantial part of sequences related to the genus Perkinsus known as strict endoparasites in both marine and freshwater 
ecosystems (Azevedo 1989, Brugerolle 2002). Investigations on the occurrence of microbial parasitism in aquatic ecosystems have mainly dealt with picoplanktonic samples containing organisms $<5 \mu \mathrm{m}$ in size (López-García et al. 2001, Lefranc et al. 2005, Richards et al. 2005, Lefèvre et al. 2008). Available data thus likely represent an underestimate of the eukaryotic microbes in pelagic ecosystems. Although the discovery of abundant parasites unveiled in diversity studies of pelagic microbial eukaryotes confirms that these organisms may play significant roles in controlling host population dynamics in aquatic systems (Lefèvre et al. 2008), challenging methodological difficulties obstruct the routine assessment of these roles.

\section{FUNGAL EPIDEMICS AND METHODOLOGICAL LIMITATIONS}

Earlier descriptions of fungal parasites were based on microscopic observation (Trow 1899) of sporangia which exhibit morphological features that can allow approximate phenotypic identification of specimens in living samples or those preserved with Lugol's iodine (Canter 1946, Lom 1970). Such approaches have provided detailed descriptions of the morphological features of true fungi and stramenopiles, primarily of chytrids (Ingold 1940, Canter 1949, 1950b, 1951), using light or phase-contrast microscopy (Sen 1987a,b, Kudoh \& Takahashi 1990) (Fig. 1A,C). Subsequently, electron microscopy was used to describe different life stages, and a number of studies describing the ultrastructural cytology of fungal zoospores and spore differentiation are available (Beakes et al. 1992a,b, 1993). The chytrid Blastocladiella sp. was the first fungal model for detailed structural studies on sporogenesis (Lovett 1963). The precise conformation of the flagellar rootlets and the spatial distribution of organelles in zoospores have been determined for both oomycetes (Schnepf et al. 1978, Sekimoto et al. 2008) and chytrids (Beakes et al. 1992a,b, 1993), providing the basis for chytrid taxonomy (Powell 1978, Barr 1992).

Ecological investigations of the dynamics of chytrid populations in natural environments have been improved more recently with epifluorescence microscopy. Several fluorochromes have been used for identifying and counting infectious fungal sporangia. The protein stain fluorescein isothiocyanate (FITC) and, in particular, the chitin stain calcofluor white (CFW) (Fig. 1B,D-H) were suggested as good markers that offer useful tools for the investigation of fungal dynamics in aquatic samples (Müller \& Sengbusch 1983). In contrast to FITC, CFW penetrates infected host cells and is more efficient for the observation of the complete rhizoidal system (Fig. 1G,H) of parasites, which is an important criterion for chytrid identification (Canter 1950a, Canter \& Lund 1951, Sparrow 1960). Hence, a CFW-based protocol was recently suggested as a routine tool for the quantitative ecology of parasitic chytrids in natural water samples, i.e. at the complex community level (Rasconi et al. 2009).

Molecular biology techniques have allowed a thorough reconstruction of parasite phylogenies (Letcher et al. 2004, James et al. 2006) and are increasingly providing more specific tools, primarily oligonucleotide probes, for the ecological study of aquatic parasites (López-García et al. 2001, Chambouvet et al. 2008, Mangot et al. 2009). Fluorescent in situ hybridisation (FISH) is a reliable approach to detect and identify specific parasitic infections, especially for parasites that are difficult to identify under a microscope based only on their phenotypes. Common examples for the latter are endoparasites, which could be diagnosed only through visual assessment of symptoms of infection, or chytrid zoospores that lack a chitinaceous wall, precluding any simple use of fluorochromes such as CFW (Rasconi et al. 2009). The sensitivity of the FISH analysis was improved through coupling with confocal microscopy, allowing the detection of early-stage infections as well as all life-cycle stages of the parasite, including the very small (3 to $5 \mu \mathrm{m}$ ) freeliving stages of Amoebophrya (Guillou et al. 2008). Recently, oligonucleotidic probes have also been used in quantitative real-time PCR (qPCR), which is an excellent tool for solving the limitations in the detection of rare species, allowing rapid and accurate quantification of endoparasites (Gachon et al. 2009). The use of qPCR has been particularly useful for studying the susceptibility of brown algae to infections from oomycete parasites such as Eurychasma sp., and the genetic determination of host resistance (Gachon et al. 2009).

Methodological difficulties help explain why only weak attempts have been made to understand the role of eukaryotic microparasites in shaping ecological communities in pelagic systems. These difficulties are increasingly being overcome. Indeed, it is becoming evident that techniques from molecular biology are useful for the study of the diversity and phylogeny of microparasites, while microscopic techniques taking advantage of specific fluorochromes or fluorescing molecular probes allow identification and quantification of infectious parasites. Furthermore, to assess the functional impact of parasites on host populations, algorithms commonly used by parasitologists have been applied in ecological studies (Bush et al. 1997). These parameters include (1) the prevalence of infection (i.e. the proportion of individuals in a given host population infected with one or more sporangium), (2) the intensity of infection (i.e. ratio between the number 


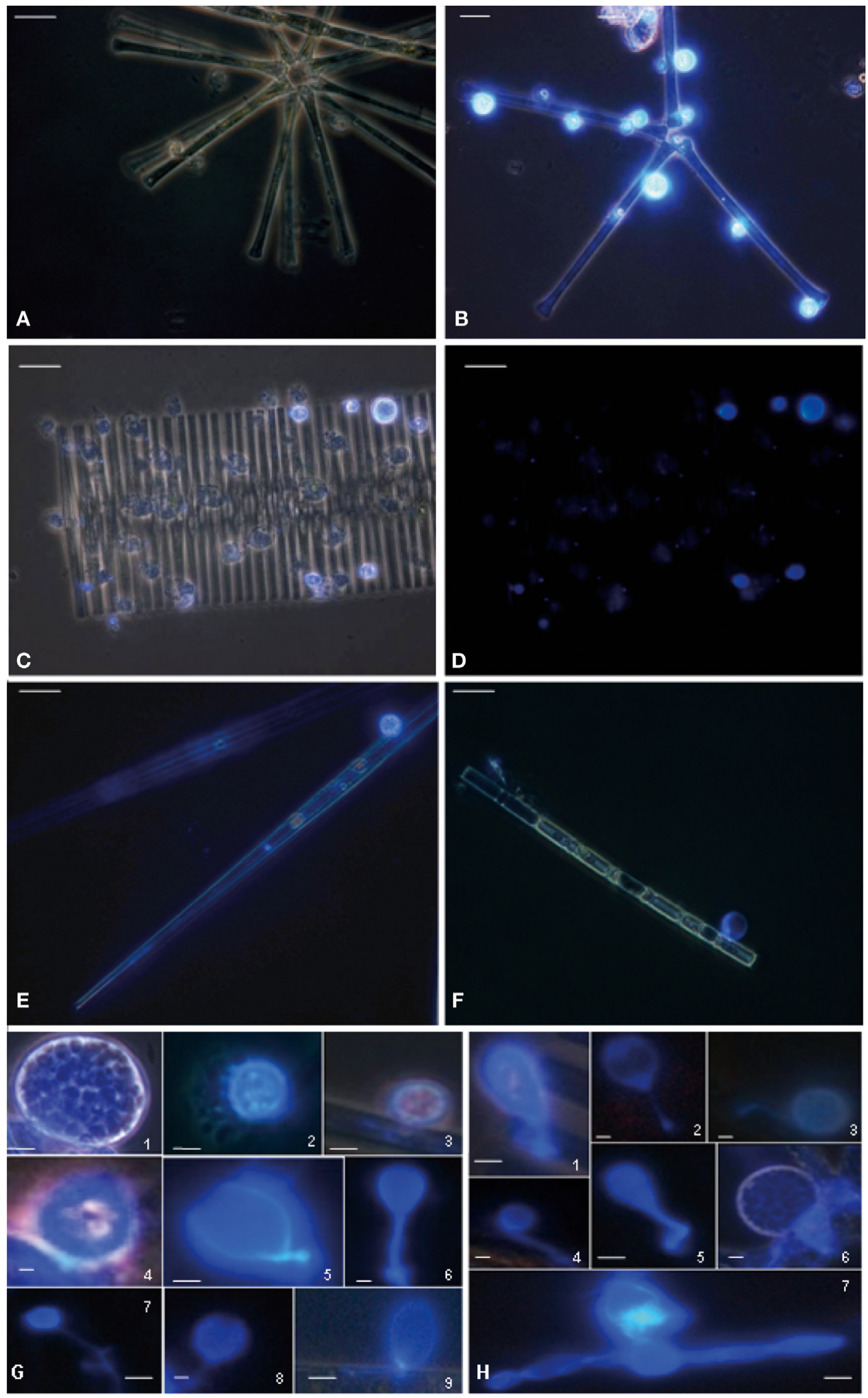


Fig. 1. Example of methodological approaches to visualize, describe, count, and identify chytrid fungi in aquatic samples. Natural, infectious, chytrid fungi on the diatoms (A,B) Asterionella formosa and (C,D) Fragilaria crotonensis visualized using $(A, C)$ light microscopy and $(B, D)$ staining the specimen with calcofluor white and using epifluorescence microscopy under UV light. We recently proposed a size-fractionation protocol based on the latter method as a routine tool for the quantitative ecology of chytrid epidemics in pelagic samples (Rasconi et al. 2009). This method yielded satisfactory images of morphological and cellular features of the host cells, and viability through the integrity of the cell wall and the presence of chloroplasts, as shown for the infected diatoms (E) Synedra acus and (F) Melosira italica. Under UV light, calcofluor white staining allows detailed description of the morphological features of sporangia $(G, 1-9)$ and of complete rhizoidal systems $(H, 1-7)$, which are critical for the determination of chytrid species based on phenotypes (cf. Rasconi et al. 2009). Scale bars $=10 \mu \mathrm{m}(\mathrm{A}-\mathrm{F})$ and $1 \mu \mathrm{m}(\mathrm{G}-\mathrm{H})$

of parasites and the number of infected individuals within a host population), and (3) the production rate of zoospores (Bruning \& Ringelberg 1987, Bruning 1991). These parameters were derived from microscopic data and are critical for assessing the seasonal dynamics of parasites, interactions with hosts, and epidemiology, as well as the potential impact of fungal parasites on the food web dynamics. Understanding the environmental factors that induce epidemics can also be inferred this way (i.e. through empirical correlations) or by using epidemiological approaches such as the changes in incidence rates (i.e. the number of new cases of infections occurring during a given time) or the occurrence of epidemics (i.e. a widespread outbreak of an infection) within host populations (Fox 2003). Using experimental approaches can also aid in exploring the effects of biotic and abiotic factors that determine the development of fungal epidemics (Bruning 1991, Bruning et al. 1992).

\section{FACTORS THAT INFLUENCE THE DEVELOPMENT OF FUNGAL EPIDEMICS}

Diverse environmental conditions, including temperature, turbulence, light, nutrient concentrations, and biotic factors such as predation or host availability for parasites, can influence the growth rate of algae, as well as those of their fungal parasites. Usually, more than a single factor is responsible for the success of host resistance to parasites or of enhanced parasite infectivity (Van Donk 1989). In addition, the fact that environmental factors affecting the growth rate of algae also affect growth parameters of their parasites is one of the reasons why it is difficult to discern environmental effects on the infectivity of chytrids, which may help explain why investigations of parasite dynamics vs. environmental conditions are not exhaustive (Canter \& Lund 1948, Sen 1987a,b, Van Donk \& Bruning 1992). For example, chytrids of the genus Rhizidium sp. and their hosts (i.e. the cyanobacteria Microcystis sp.) are both favoured by temperatures $>15^{\circ} \mathrm{C}$ at optimum $\mathrm{pH}$ of about 7.3 (Sen 1988). Laboratory cultures and the maintenance of host-parasite systems growing under controlled con- ditions (Bruning \& Ringelberg 1987, Bruning 1991) have suggested that the optimum temperature for fungal growth is highly variable and can be speciesspecific, generally ranging from $3^{\circ} \mathrm{C}$ (Van Donk \& Ringelberg 1983) to $30^{\circ} \mathrm{C}$ (Barr \& Hickman 1967). In freshwater environments, chytrids, especially those that infect diatoms, have a high affinity for low water temperatures (Ibelings et al. 2003). Sporangia were even reported under ice conditions, with a high infection level (Canter \& Lund 1951, Sen 1987b). The level of pathogenesis in infected host communities can also be influenced by global environmental stress such as climate change and habitat alteration (Sures 2003, Smith et al. 2009). For example, fungal chytridiomycosis due to Batrachochytrium dendrobatidis, one of the most deadly contemporary skin diseases that drive the decline of amphibian populations worldwide (Voyles et al. 2009), increases as temperature increases and shifts towards the growth optimum of the fungus (Pounds et al. 2006). Global environmental disturbances can also increase the susceptibility of uninfected hosts when exposed to parasites, as shown for microsporidian infections in crayfish; these infections are enhanced by acidification due to acid rain (France \& Graham 1985).

Paterson (1967) recognizes that turbulence of water is an important factor in determining fungal periodicity, and that spore germination may coincide with the seasonal establishment of thermal stratification in lakes. Infectivity of chytrid zoospores was discussed by Canter \& Jaworski (1978, 1979), indicating light perception by zoospores and inhibition of zoospore attachment to hosts in dark conditions. Chytrid zoospores can also use photosynthesis-related excretion products from their hosts to find or recognize the latter, implying that light can interfere with chemotaxis in determining chytridiomycosis within phytoplankton populations (Moss et al. 2008). High nutrient concentrations are favourable for algal growth, and can in turn also enhance the development of parasites (Canter \& Lund 1969). Phosphorus-limited conditions are indeed known to decrease chytrid zoospore production (Bruning 1991). However, the functional responses of fungal parasites to changes in the trophy of ecosystems have received little attention in the literature. 
One of the biotic factors that are crucial to the proliferation of fungal parasites is zooplankton predation of fungal zoospores. In laboratory experiments, chytrid infections of phytoplankton can be decreased by introducing grazers (Kagami et al. 2004). In natural conditions, some authors have found that the diatom Asterionella formosa is less severely infected by the chytrid Rhizophidium planktonicum in summer than in winter (Canter \& Lund 1953, Kudoh \& Takahashi 1990), probably because of the greater affinity of diatoms to cold waters, but also due to the fact that zooplankton grazers are less active in cold seasons. Finally, the primary factor determining the absence or the presence of a particular parasite in an environment is the availability of suitable hosts. For some species, epidemics can occur at relatively low algal densities, but in many cases, a threshold density is needed. This threshold value differs between algal species but generally seems to decrease with increasing host size. For example, fungal epidemics were described at host densities as low as 10 cells ml $^{-1}$ for the large (average cell length $50 \mu \mathrm{m}$ ) diatom Asterionella spp. (Lund 1957), whereas for the smaller (average cell length $20 \mu \mathrm{m}$ ) cholorophyte Ankyra judayi, fungal epidemics could not be detected at a host density below 50 cells $\mathrm{ml}^{-1}$ (Holfeld 1998). Furthermore, positive correlations were reported between the size of mature sporangia, the production rate of zoospores, and the host cell size (Holfeld 2000). It is thus likely that in contrast to small edible hosts, large inedible hosts offer more refuge, resources, and ecological niches for chytrid parasites. The contrasting effect of zooplankton predation and chytrid infections relative to the size and edibility of the common phytoplankton resources can be critical for the food web structure and dynamics.

\section{ECOLOGICAL POTENTIAL OF PARASITES}

\section{General considerations on parasitism}

Parasites depend on hosts for growth and reproduction, and the majority of studies have focused on the genetics and morphological or behavioural issues for hosts. Little has been done to establish the ecological importance of infectious agents per se and the consequences of their activities at the host community and food web levels (Marcogliese \& Cone 1997). Among the constraints imposed on host populations by parasites are modifications of behaviour, castration or weakened reproduction (i.e. fitness), changes in the numerical abundance, and parasite-induced mortality. Marcogliese (2004) provides a detailed table with several examples of parasites and their effects on hosts in aquatic ecosystems. The majority of parasites do not kill their hosts (although death can result from infection) but instead form chronic associations with their victims, reducing host fitness rather than survival; these parasites can even allow infected hosts to remain competitors within the community (Fenton \& Brockhurst 2008). The parasitic-forcing of changes in host behaviour is the case for some parasitic helminths (Cestoda), which affect foraging and reduce growth in sticklebacks (Barber \& Huntingford 1995), or of castrators like trematodes, which have no discernible effect on the longevity of their hosts (i.e. snails) but can stop host reproduction (Lafferty 2008). In addition, parasitism can be fostered by high host diversity and abundance (Hechinger \& Lafferty 2005), and the parasitic infections can interplay with other factors that determine the density and viability of host populations.

Infectious agents can influence evolutionary and ecological processes of host populations. Parasitism affects major ecological interactions such as competitive ability for resource uptake among species and often determines the dominant species in a community by enabling the success of subordinate or numerically minor species (Lafferty 2008). Along North Atlantic coasts, expansion of macroalgal cover is a direct consequence of the trematode infection of herbivorous snails (Wood et al. 2007). Similarly, heavy infections of cockles by trematodes in intertidal communities on New Zealand's South Island make infected individuals more sessile and leave them unable to bury themselves in the substrate. This behavioural change affects the stability of the substrate with benefits to benthic organisms, primarily gastropods (Mouritsen \& Poulin 2005). Parasites are thus important in species coexistence, shaping biodiversity and the genetic composition of natural communities, and even in promoting speciation (Janz et al. 2006). Indeed, as a highly density-dependent phenomenon, and because parasites tend to be host specific, dispersal limitation selects for higher transmission of infections among the most abundant species. Natural populations that are numerically rich in hosts are also rich in parasites, and the diversity of parasites reflects the overall diversity within the system (Hechinger \& Lafferty 2005). Hence, parasites can affect a number of trophic links and render the natural food web organization more complex (Lafferty \& Kuris 2002, Amundsen et al. 2009). Parasites promote long food chains and multispecies connections known to stabilize the community structure (compared to short food chains), thereby increasing the resilience and persistence of ecosystems (Hudson et al. 2006). In addition, many parasites have free-living stages that can be grazed, establishing parasites not only as drivers of food chain properties but also as a trophic link per se (Lafferty et al. 2006). 
The above considerations fully justify recent calls for the inclusion of parasites other than viruses in pelagic ecology and food web dynamics (McCallum et al. 2004, Amundsen et al. 2009), instead of limiting the parasitic scope to infectious diseases of plants or animals of economical interest, such as fishes and shellfish (Sindermann 1990). This inclusion is of particular importance for primary producers which form the root of food webs in pelagic ecosystems and are now known to harbour diverse microbial parasites, infecting both prokaryotes and eukaryotes (Rasconi et al. 2009).

\section{The case of phytoplanktonic fungal parasites (chytrids)}

In marine and freshwater ecosystems, algae are widespread, diversified, and intrinsically fundamental to food web dynamics. So far, little is known about the host-parasite interactions and the consequences of infections on the structure and activity of host populations at the complex natural community level.

Perhaps the best documented role of fungal epidemics is the control of freshwater algal populations by parasitic chytrids. Since the middle of the last century, it has been shown that chytrids control the dynamics of Staurastrom paradoxum in the Swithland Reservoir, UK (Reynolds 1940). Since then, chytrid epidemics have been reported from numerous lakes, for example in Windermere and Shearwater, UK (Canter \& Lund 1948, Sen 1987b), Lake Geneva (or Lac Leman), Switzerland (Pongratz 1966), Lake Maarsseveen, The Nederlands (Van Donk \& Ringelberg 1983), Lake Lanier, Georgia, USA (Doggett \& Porter 1995), Lake Biwa, Japan (Kagami \& Urabe 2002), and Lakes Pavin and Aydat, France (Rasconi et al. 2009). In such environments, chytrids have been linked to mass mortalities of host organisms, suppression or retardation of phytoplankton blooms, and selective effects on species composition and successions (Van Donk \& Ringelberg 1983). Parasitic chytrids have been observed growing on a large number of phytoplankton species (Bruning 1991, Kagami et al. 2007b, Rasconi et al. 2009), and up to $90 \%$ of host cells in a population can be infected (Canter \& Lund 1951, Van Donk \& Ringelberg 1983). In general, the disease decreases the size of host populations or at least delays their peak (Sen 1987a, Kudoh \& Takahashi 1990). Such massive infections of eukaryotes have also been reported in marine environments for Syndiniales parasites infecting dinoflagellate species (Chambouvet et al. 2008, Guillou et al. 2008), at times with the parasites having more impact than grazers on host populations (Montagnes et al. 2008). Chytrids also infect diverse colonial and filamentous cyanobacteria such as Anabaena flosaquae, Gomphos- phaeria sp. or Microcystis sp. in productive lakes (Rasconi et al. 2009). The idea that both prokaryotic and eukaryotic phytoplankton are subject to infections from eukaryotic microparasites is not new, but the ecological significance of the host-parasite interactions, the consequences for the food web dynamics, and the related biogeochemical cycling remain to be fully addressed.

In general, fungal infections are species-specific interactions and can favour the development of less abundant and rare species or interfere in the competition between species or clones sharing similar niches. Canter \& Lund (1951) found that the highly infected diatom Asterionella formosa in Esthwaite waters, Lake District, UK was replaced by Tabellaria fenestrata, while the total standing stock of diatoms in the area remained constant. Later, the same authors reported a similar constant seasonal abundance of the desmids Staurastrum spp., despite significant changes in their genetic structure (i.e. species composition) due to parasitic infection. Indeed, the total community did not decline during the period of maximum parasitic infection, because the biomass losses from the declining species $S$. cingulum and $S$. planktonicum were compensated for by an increase in S. lunatum (Canter \& Lund 1969). Fungal parasitism can thus have significant effects on the host population genetics, and these effects can remain completely cryptic based on the numerical abundance of hosts. One of the evoked mechanisms is coevolution, which is the reciprocal natural selection of host resistance vs. parasite infectivity. High host densities select for higher virulence, and during host blooms, parasites can optimize their virulence when the host population is genetically more uniform (Brown et al. 2002) and exhibits short generation times. Local adaptation occurs when infection rates by parasites are higher in their own local populations than in foreign populations (Gandon \& Van Zandt 1998). In Lake Maarsseveen (The Netherlands), infections of the diatoms Asterionella sp. frequently affect $100 \%$ of individuals, suggesting weak genetic variability within host populations that optimizes the virulence of parasites (Van Donk \& Ringelberg 1983). This has also been tested experimentally for the diatomchytrid system Asterionella-Zygorhizidium maintained in laboratory cultures (De Bruin et al. 2004).

Functional responses of hosts to fungal parasitism are complex for a wide variety of host-pathogen combinations (Wood 2007 ), the most common being hypersensitivity (Maclean et al. 1974), i.e. a form of programmed cell death which is recurrent in plants (Yao et al. 2002), including algae (Canter \& Jaworski 1978). Canter \& Jaworski (1979) noted that hypersensitivity occurs in some cultured clones of diatoms Asterionella formosa parasitized by the chytrid Rhizophidium 
planktonicum. Hypersensitivity often is the expression of specific genes (Collinge \& Slusarenko 1987), and their modifications in response to fungal infections are crucial to host survival. One of the strategies is sexuality, i.e. a powerful generator of genetic variations known to allow parasites to adapt to every new host genotype they encounter (De Bruin 2006). Generalist parasites would evolve a strategy of having an intermediate level of virulence across a wide range of hosts, while a high level of virulence would be indicative of specialist parasites, which require high metabolic costs for switching between hosts (Regoes et al. 2000). Thus, the mean fitness of microparasites is likely higher when infecting sympatric rather than allopatric hosts (Kaltz \& Shykoff 1998), although the generally shorter life cycles of microparasites may provide coevolutionary advantages. The potential for local adaptation of parasites may depend on the geographical scale and the differential effects of selection and migration on host and parasite populations. Overall, because parasites can reduce host abundance but also promote sexual reproduction and the related genetic recombination, they are potential ecologically important actors in community structuring.

In the context of the microbial loop and food web dynamics (Azam et al. 1983), the recent findings of small eukaryotes phylogenetically related to zoosporic fungal parasites (Lefèvre et al. 2007, 2008) have significant ecological potential and can improve our understanding of the carbon flow in pelagic ecosystems (Gleason et al. 2008). In these systems, heterotrophic flagellates are exclusively regarded as bacterivorous protists and are frequently considered the key trophic link between dissolved organic matter and higher trophic levels via bacterial production (Sherr \& Sherr 1994, Azam 1998). However, there is a general lack of relationship between bacteria and their presumed flagellate grazers when comparing aquatic ecosystems worldwide (Gasol \& Vaqué 1993). We believe that one of the explanations undoubtedly lies in the trophic complexity within small flagellate assemblages, which includes phagotrophy, but also parasitism and other trophic modes (e.g. saprotrophy and symbiosis) known from fungi (Gleason et al. 2008, 2009). The amount of zoospores produced during fungal epidemics is in the same order of magnitude as the abundance of the socalled heterotrophic nanoflagellates, both of which are food sources for zooplankton (Kagami et al. 2004) but with quite different trophic strategies (e.g. parasitism vs. phagotrophy). Parasitic chytrids will, for example, increase the residence time of their preferred large inedible hosts (such as the algae Asterionella, Fragilaria or Staurastrum) in the water column, where hosts are converted into zoospores (Lefèvre et al. 2008) which are available for the higher trophic levels
(Fig. 2). Lipid analyses have revealed that these zoospores contain oil globules that are rich in sterol, especially cholesterol and polyunsaturated fatty acids (PUFAs), known to promote and even upgrade the growth and reproduction of grazers (Klein Breteler et al. 1999, Kagami et al. 2007a). Including microparasites such as zoosporic fungi may thus modify the food web scheme in pelagic ecosystems and reveal consistent pathways of energy flows (Fig. 2), which, together with parasite- host life histories, suggest stable evolutionary groups of neglected interacting species within the microbial community.

\section{OTHER PERSPECTIVES AND PENDING QUESTIONS}

Ecological knowledge of microscopic fungal parasites in aquatic environments is inadequate (Wurzbacher et al. 2010) compared to terrestrial ecosystems. The phytoplankton compartment appears to be a major target host compartment for parasitic zoosporic fungi, which could thus affect the productivity of pelagic systems. Studies show that species eliminated by their specific fungal parasites can be replaced by ecologically similar species with regard to resource exploitation (Canter \& Lund 1969), but with different susceptibility to grazing pressure. For example, infection of large grazing-resistant species can favour the development of smaller species, which are resistant to infection but highly exposed to grazing. Severe consequences can thus be expected for the structure of the phytoplankton host community. Reynolds (1973) reported that one of the important effects of infection by the chytrid Zygorhizidium affluens of the diatom Asterionella sp. (mean length $50 \mu \mathrm{m}$ ) was to allow the dominance of the diatom Stephanodiscus astrea $(10 \mu \mathrm{m})$. Similarly, Sommer (1987) found that the infected diatom Fragilaria sp. $(70 \mu \mathrm{m})$ was replaced by the diatom Stephanodiscus binderanus $(10 \mu \mathrm{m})$ in Lake Constance. From these examples, we predict that parasitism could change the phytoplankton structure from a mature stage of development typically dominated by competitive $\mathrm{k}$-selected species, towards a pioneer stage of succession, by allowing the development of fast growing r-selected species. Parasitic fungi can thus have profound effects on phytoplankton successions (sensu Odum 1969).

Beside the potential roles evoked for chytrid parasites in the shunt of energy from phytoplankton towards zooplankton via grazing of zoospores, it is important to realize that host-parasite coevolution is a dynamic process that depends on genotypes of both components. Related models elaborated for terrestrial ecosystems (Carius et al. 2001) suggest that environ- 


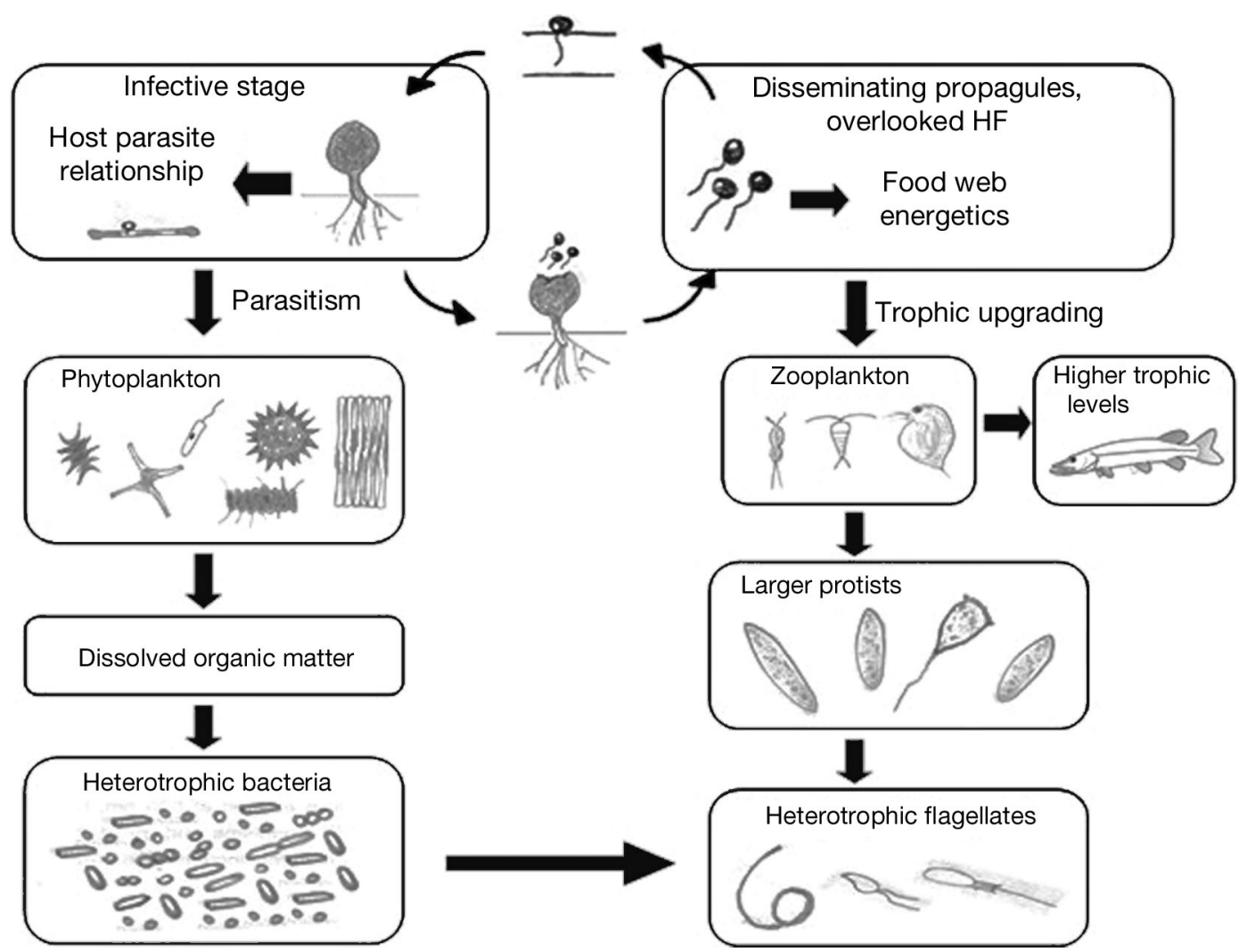

Fig. 2. Two stages of fungal parasites of phytoplankton differently affect the structure of an idealized aquatic food web. Infective stages (sporangia) weaken phytoplankton growth and increase the retention time of organic material in the water column, whereas propagules (zoospores) are food for zooplankton, which can provide more energy for the higher trophic levels. The relative importance of the 2 overlooked pathways (i.e. infection and food resource) for energy and material flows remains unknown. $\mathrm{HF}=$ heterotrophic flagellates

mental factors which impact host populations (e.g. introduction of alien species, global warming, acid rain, and eutrophication) may also drive parasites to adapt to changed hosts. Some algal species (mostly Asterionella sp. and other diatoms, but also some desmids such as Staurastrum sp.) are parasitized at a global scale (Doggett \& Porter 1995, Gromov et al. 1999, Kagami \& Urabe 2002). Biogeography studies might thus be important for a better understanding of how fungal parasites have colonized most of the diatoms in pelagic inland waters. Lakes are isolated environments with presumably restricted gene flows, representing interesting sites for the study of the virulence of fungal parasites on certain species of algae. If we consider that genetic variations in diatoms would be limited due to their long reproductive cycles, then the related low gene recombination may increase their vulnerability to parasitism. Molecular tools are being increasingly used to study genetic variation in phytoplankton populations and the latters' specificity to certain microparasites (Gachon et al. 2009), creating the opportunity for extensive research on host-range genotyping (Ebert 1994). Data on the genes involved in host resistance or susceptibility are lacking, as is the potential of parasites to adapt to a wide range of host genotypes (De Bruin 2006).

Fungal parasitism damages their phytoplanktonic hosts (Canter \& Lund 1948, Sparrow 1960, Van Donk \& Ringelberg 1983), thereby weakening the primary production that sustains the food web. By providing upgraded food sources (i.e. as zoospores) for zooplankton (Kagami et al. 2007a) and labile substrates for prokaryotes, parasitism can thus change the balance between auto- and heterotrophy in pelagic systems. Because primary production shapes the community composition of prokaryotes (Horner-Devine et al. 2003), phytoplankton parasites affect microbial diversity. There is also evidence that increasing productivity generally results in an increase of the food chain length (Kaunzinger \& Morin 1998), but nothing is known about the incidence of parasitism in this scenario. Finally, long-term ecological data are necessary to understand the effects of environmental stress on parasite-host interactions in aquatic systems. 
Acknowledgements. S.R. and M.J. were supported by PhD Fellowships from the Grand Duché du Luxembourg (Ministry of Culture, High School, and Research) and from the French Ministère de la Recherche et de la Technologie (MRT), respectively. We thank C. Rasconi and J. Sauvanet for their help with the drawings in Fig. 2. This study was supported by a grant from the French ANR Programme Blanc 'DREP: Diversité et Rôles des Eumycètes dans le Pélagos'; Coordinator T.S.-N.

\section{LITERATURE CITED}

Amundsen PA, Lafferty KD, Knudsen R, Primicerio R, Klemetsen A, Kuris AM (2009) Food web topology and parasites in the pelagic zone of a subarctic lake. J Anim Ecol 78: 563-572

Anderson RM, May RM (1979) Population biology of infectious diseases: Part I. Nature 280:361-367

Anderson RM, May RM (1981) The population dynamics of microparasites and their invertebrate hosts. Phil Trans R Soc Lond B 291:451-524

Azam F (1998) Microbial control of oceanic carbon flux: the plot thickens. Science 280:694-696

- Azam F, Fenchel T, Field JG, Gray JS, Meyer-Reil LA, Thingstad F (1983) The ecological role of water-column microbes in the sea. Mar Ecol Prog Ser 10:257-263

Azevedo C (1989) Fine structure of Perkinsus atlanticus n. sp. (Apicomplexa, Perkinsea) parasite of the clam Ruditapes decussatus from Portugal. J Parasitol 75:627-635

Barber I, Huntingford FA (1995) The effect of Schistocephalus solidus (Cestoda: Pseudophyllidea) on the foraging and shoaling behaviour of three-spined sticklebacks, Gasterosteus aculeatus. Behaviour 132:1223-1240

Barr DJS (1990) Phylum Chytridiomyceta. In: Margulis L, Corliss JO, Melkonian M, Chapman DJ (eds) Handbook of Protoctista. Jones and Bartlett Publishers, Boston, MA, p 454-466

Barr DJS (1992) Evolution and kingdoms of organisms from the perspective of a mycologist. Mycologia 84:1-11

Barr DJS, Hickman CJ (1967) Chytrids and algae I: Host-substrate range, and morphological variation of species of Rhizophydium. Can J Bot 45:423-430

Beakes GW, Canter HM, Jaworski GH (1992a) Comparative ultrastructural ontogeny of zoosporangia of Zygorhizidium affluens and $Z$. planktonicum, chytrid parasites of the diatom Asterionella formosa. Mycol Res 96:1047-1059

Beakes GW, Canter HM, Jaworski GH (1992b) Ultrastructural study of operculation (discharge apparatus) and zoospore discharge in zoosporangia of Zygorhizidium affluens and Z. planktonicum, chytrid parasites of the diatom Asterionella formosa. Mycol Res 96:1060-1067

Beakes GW, Canter HM, Jaworski GHM (1993) Sporangium differentiation and zoospore fine-structure of the chytrid Rhizophydium planktonicum, a fungal parasite of Asterionella formosa. Mycol Res 97:1059-1074

Bergh Ø, Børsheim KY, Bratbak G, Heldal M (1989) High abundance of viruses found in aquatic environments. Nature 340:467-468

Brown SP, Hochberg ME, Grenfell BT (2002) Does multiple infection select for raised virulence? Trends Microbiol 10:401-405

- Brugerolle G (2002) Cryptophagus subtilis: a new parasite of cryptophytes affiliated with the Perkinsozoa lineage. Eur J Protistol 37:379-390

Bruning K (1991) Infection of the diatom Asterionella by a chytrid. I. Effects of light on reproduction and infectivity of the parasite. J Plankton Res 13:103-117
Bruning K, Ringelberg J (1987) The influence of phosphorus limitation of the diatom Asterionella formosa on the zoospore production of its fungal parasite Rhizophydium planktonicum. Aquat Ecol 21:49-54

Bruning K, Lingeman R, Ringelberg J (1992) Estimating the impact of fungal parasites on phytoplankton populations. Limnol Oceanogr 37:252-260

Buschmann AH, Correa JA, Westermeier R, HernándezGonzález MC, Norambuena R (2001) Red algal farming in Chile: a review. Aquaculture 194:203-220

Bush AO, Lafferty KD, Lotz JM, Shostak AW (1997) Parasitology meets ecology on its own terms: Margolis et al. revisited. J Parasitol 83:575-83

- Canter HM (1946) Studies on British chytrids. I. Dangeardia mammillata Schrödor. Trans Br Mycol Soc 29:128-134

> Canter HM (1949) Studies on British chytrids. VI. Aquatic Synchytriaceae. Trans Br Mycol Soc 32:22-29

Canter HM (1950a) Fungal parasites of the phytoplankton. I (Studies on British chytrids, X). Ann Bot 14:263-289

> Canter HM (1950b) Studies on British chytrids. XI. Chytridium oedogonii Couch. Trans Br Mycol Soc 33:354-358

Canter HM (1951) Fungal parasites of the phytoplankton. II (Studies on British Chytrids, XII). Ann Bot 15:129-156

Canter HM, Jaworski GHM (1978) The isolation, maintenance and host range studies of a chytrid Rhizophydium planktonicum Canter emend., parasitic on Asterionella formosa Hassall. Ann Bot 42:967-979

Canter HM, Jaworski GHM (1979) The occurrence of a hypersensitive reaction in the planktonic diatom Asterionella formosa Hassall parasitized by the chytrid Rhizophydium planktonicum Canter emend. in culture. New Phytol 82: 187-206

Canter HM, Lund JWG (1948) Studies on plankton parasites. I. Fluctuations in the numbers of Asterionella formosa Hass. in relation to fungal epidemics. New Phytol 47:238-261

Canter HM, Lund JWG (1951) Studies on plankton parasites. III. Examples of the interaction between parasitism and other factors determining the growth of diatoms. Ann Bot 15:359-371

Canter HM, Lund JWG (1953) Studies on plankton parasites II. The parasitism of diatoms with special reference to lakes in the English Lake District. Trans Br Mycol Soc 36: 13-37

Canter HM, Lund JWG (1969) The parasitism of planktonic desmids by fungi. Plant Syst Evol 116:351-377

Carius HJ, Little TJ, Ebert D (2001) Genetic variation in a host-parasite association: potential for coevolution and frequency-dependent selection. Evolution 55:1136-1145

Cavalier-Smith T (1993) Kingdom protozoa and its 18 phyla. Microbiol Mol Biol Rev 57:953-994

Chambouvet A, Morin P, Marie D, Guillou L (2008) Control of toxic marine dinoflagellate blooms by serial parasitic killers. Science 322:1254-1257

> Coats DW, Adam EJ, Gallegos CL, Hedrick S (1996) Parasitism of photosynthetic dinoflagellates in a shallow subestuary of Chesapeake Bay, USA. Aquat Microb Ecol 11:1-9

Collinge DB, Slusarenko AJ (1987) Plant gene expression in response to pathogens. Plant Mol Biol 9:389-410

Comeau AM, Krisch HM (2005) War is peace-dispatches from the bacterial and phage killing fields. Curr Opin Microbiol 8:488-494

Da Silva WM, Roche KF, De Vicente FS, Delben AA (2009) First record of the peritrich Trichodina diaptomi Basson and Van As, 1991 (Protozoa: Ciliophora) on a South American calanoid Notodiaptomus deitersi (Poppe, 1890) (Crustacea: Copepoda). J Eukaryot Microbiol 56:385 A 
De Bruin A (2006) The potential of co-evolution in an aquatic host-parasite system. PhD thesis, Netherlands Institute of Ecology, Amsterdam

> De Bruin A, Ibelings BW, Rijkeboer M, Brehm M, Van Donk E (2004) Genetic variation in Asterionella formosa (Bacillariophyceae): Is it linked to frequent epidemics of host-specific parasitic fungi? J Phycol 40:823-830

De Bruin A, Ibelings BW, Kagami M, Mooij WM, Van Donk E (2008) Adaptation of the fungal parasite Zygorhizidium planktonicum during 200 generations of growth on homogeneous and heterogeneous populations of its host, the diatom Asterionella formosa. J Eukaryot Microbiol 55: 69-74

Demergasso C, Casamayor EO, Chong G, Galleguillos P, Escudero L, Pedrós-Alió C (2004) Distribution of prokaryotic genetic diversity in athalassohaline lakes of the Atacama Desert, Northern Chile. FEMS Microbiol Ecol 48:57-69

Desvilettes C, Bec A (2009) Formation and transfer of fatty acids in aquatic microbial food webs - role of heterotrophic protists. In: Arts MT, Brett M, Kainz M (eds) Lipids in aquatic ecosystems. Springer, New York, NY, p 25-42

> Diez B, Pedrós-Alió C, Massana R (2001) Study of genetic diversity of eukaryotic picoplankton in different oceanic regions by small-subunit rRNA gene cloning and sequencing. Appl Environ Microbiol 67:2932-2941

Doggett MS, Porter D (1995) Further evidence for host-specific variants in Zygorhizidium planktonicum. Mycologia 87:161-171

Ebert D (1994) Virulence and local adaptation of a horizontally transmitted parasite. Science 265:1084-1086

Ebert D (2005) Ecology, epidemiology, and evolution of parasitism in Daphnia. National Library of Medicine, Bethesda, MD

Fenton A, Brockhurst M (2008) The role of specialist parasites in structuring host communities. Ecol Res 23:795-804

Fox A (2003) Glossary of epidemiological terms. The Internet Journal of Pediatrics and Neonatology 3 (www.ispub.com)

France RL, Graham L (1985) Increased microsporidian parasitism of the crayfish Orconectes virilis in an experimentally acidified lake. Water Air Soil Pollut 26:129-136

Fryer JL, Rohovec JS (1993) Bacterial diseases of fish. In: Couch JA, Fournie JW (eds) Pathology of marine and estuarine organisms. CRC Press, Boca Raton, FL p 53-83

Fryer JL, Sanders JE (1981) Bacterial kidney disease of salmonid fish. Annu Rev Microbiol 35:273-298

Fuhrman JA (1999) Marine viruses and their biogeochemical and ecological effects. Nature 399:541-548

- Gachon CM, Strittmatter M, Müller DG, Kleinteich J, Küpper FC (2009) Differential host susceptibility to the marine oomycete pathogen Eurychasma dicksonii detected by real time PCR: not all algae are equal. Appl Environ Microbiol 75:322-328

Gandon S, Van Zandt PA (1998) Local adaptation and hostparasite interactions. Trends Ecol Evol 13:214-216

> Gasol JM, Vaqué D (1993) Lack of coupling between heterotrophic nanoflagellates and bacteria: a general phenomenon across aquatic systems? Limnol Oceanogr 38:657-665

Gleason FH, Macarthur D (2008) The chytrid epidemic revisited. Inoculum 59(2):1-3

> Gleason FH, Kagami M, Lefèvre E, Sime-Ngando T (2008) The ecology of chytrids in aquatic ecosystems: roles in food web dynamics. Fungal Biol Rev 22:17-25

Gleason FH, Kagami M, Marano AV, Sime-Ngando T (2009) Fungal zoospores are valuable food resources in aquatic ecosystems. Inoculum 60(5):1-3

$>$ Green J (1974) Parasites and epibionts of Cladocera. Trans Zool Soc Lond 32:417-515
Gromov BV, Plujusch AV, Mamkaeva KA (1999) Morphology and possible host range of Rhizophydium algavorum sp. nov. (Chytridiales): an obligate parasite of algae. Protistology 1:62-65

Guillou L, Viprey M, Chambouvet A, Welsh RM and others (2008) Widespread occurrence and genetic diversity of marine parasitoids belonging to Syndiniales (Alveolata). Environ Microbiol 10:3349-3365

Hechinger RF, Lafferty KD (2005) Host diversity begets parasite diversity: bird final hosts and trematodes in snail intermediate hosts. Proc R Soc Lond 272:1059-1066

Holfeld H (1998) Fungal infections of the phytoplankton: seasonality, minimal host density, and specificity in a mesotrophic lake. New Phytol 138:507-517

Holfeld H (2000) Relative abundance, rate of increase, and fungal infections of freshwater phytoplankton. J Plankton Res 22:987-995

Horner-Devine MC, Leibold MA, Smith VH, Bohannan BJ (2003) Bacterial diversity patterns along a gradient of primary productivity. Ecol Lett 6:613-622

- Hudson PJ, Dobson AP, Lafferty KD (2006) Is a healthy ecosystem one that is rich in parasites? Trends Ecol Evol 21:381-385

Ibelings BW, De Bruin A, Van Donk E (2003) Parasitic fungi on freshwater phytoplankton. In: Tsui CKM, Hyde KD, Ho WH (eds) Freshwater mycology. Fungal Diversity Press, Hong Kong, p 11-51

Ibelings BW, De Bruin A, Kagami M, Rijkeboer M, Brehm M, Van Donk E (2004) Host parasite interactions between freshwater phytoplankton and chytrid fungi (Chytridiomycota). J Phycol 40:437-453

> Ingold CT (1940) Endocoenobium eudorinae gen. et sp. nov., a chytridiaceous fungus parasitizing Eudorina elegans Ehrenb. New Phytol 39:97-103

James TY, Letcher PM, Longcore JE, Mozley-Standridge SE and others (2006) A molecular phylogeny of the flagellated fungi (Chytridiomycota) and description of a new phylum (Blastocladiomycota). Mycologia 98: $860-871$

Janz N, Nylin S, Wahlberg N (2006) Diversity begets diversity: host expansions and the diversification of plant-feeding insects. BMC Evol Biol 6:4

Jobard M, Rasconi S, Sime-Ngando T (2010) Diversity and functions of microscopic fungi: a missing component in pelagic food webs. Aquat Sci 72:255-268

Johnson PTJ, Ives AR, Lathrop RC, Carpenter SR (2009) Longterm disease dynamics in lakes: causes and consequences of chytrid infections in Daphnia populations. Ecology 90: 132-144

Kagami M, Urabe J (2002) Mortality of the planktonic desmid, Staurastrum dorsidentiferum, due to interplay of fungal parasitism and low light conditions. Verh Int Ver Theor Angew Limnol 28:1001-1005

> Kagami M, Van Donk E, de Bruin A, Rijkeboer M, Ibelings BW (2004) Daphnia can protect diatoms from fungal parasitism. Limnol Oceanogr 49:680-685

> Kagami M, de Bruin A, Ibelings BW, Van Donk E (2007a) Parasitic chytrids: their effects on phytoplankton communities and food-web dynamics. Hydrobiologia 578: 113-129

Kagami M, Von Elert E, Ibelings BW, De Bruin A, Van Donk E (2007b) The parasitic chytrid, Zygorhizidium, facilitates the growth of the cladoceran zooplankter, Daphnia, in cultures of the inedible alga, Asterionella. Proc R Soc Lond 274:1561-1566

Kaltz O, Shykoff JA (1998) Local adaptation in host-parasite systems. Heredity 81:361-370 
Kaunzinger CMK, Morin PJ (1998) Productivity controls foodchain properties in microbial communities. Nature 395: 495-497

Klein Breteler WCM, Schogt N, Baas M, Schouten S, Kraay GW (1999) Trophic upgrading of food quality by protozoans enhancing copepod growth: role of essential lipids. Mar Biol 135:191-198

Kudoh S, Tokahashi M (1990) Fungal control of population changes of the planktonic diatom Asterionella formosa in a shallow eutrophic lake. J Phycol 26:239-244

Kuris AM, Hechinger RF, Shaw JC, Whitney KL and others (2008) Ecosystem energetic implications of parasites and free-living biomass in three estuaries. Nature 7203: $515-518$

Lafferty KD (2008) Effects of disease on community interactions and food-web structure. In: Ostfeld R, Keesing F, Eviner V (eds) Infectious disease ecology: effects of disease on ecosystems and of ecosystems on disease. Princeton University Press, Princeton, NJ, p 205-222

Lafferty KD, Kuris AM (2002) Trophic strategies, animal diversity and body size. Trends Ecol Evol 17:507-513

Lafferty KD, Dobson AP, Kuris AM (2006) Parasites dominate food web links. Proc Natl Acad Sci USA 103:11211-11216

Latijnhouwers M, de Wit PJ, Govers F (2003) Oomycetes and fungi: similar weaponry to attack plants. Trends Microbiol 11:462-469

Lefèvre E, Bardot C, Noël C, Carrias JF, Viscogliosi E, Amblard C, Sime-Ngando T (2007) Unveiling fungal zooflagellates as members of freshwater picoeukaryotes: evidence from a molecular diversity study in a deep meromictic lake. Environ Microbiol 9:61-71

Lefèvre E, Roussel B, Amblard C, Sime-Ngando T (2008) The molecular diversity of freshwater picoeukaryotes reveals high occurrence of putative parasitoids in the plankton. PLOS ONE 3:e2324

Lefranc M, Thénot A, Lepere C, Debroas D (2005) Genetic diversity of small eukaryotes in lakes differing by their trophic status. Appl Environ Microbiol 71:5935-5942

> Letcher PM, Powell MJ, Chambers JG, Holznagel WE (2004) Phylogenetic relationships among Rhizophydium isolates from North America and Australia. Mycologia 96: 1339-1351

Li M, Wang J, Zhu D, Gu Z, Zhang J, Gong X (2008) Study of Apiosoma piscicola (Blanchard 1885) occurring on fry of freshwater fishes in Hongze, China with consideration of the genus Apiosoma. Parasitol Res 102:931-937

Lindell D, Jaffe JD, Johnson ZI, Church GM, Chisholm SW (2005) Photosynthesis genes in marine viruses yield proteins during host infection. Nature 438:86-89

Logares R, Braate J, Bertilsson S, Clasen JL, ShalchianTabrizi K, Rengefors K (2009) Infrequent marine-freshwater transitions in the microbial world. Trends Microbiol $17: 414-422$

Lom J (1970) Observations on trichodinid ciliates from freshwater fishes. Arch Protistenkd 112:153-177

López-García P, Rodríguez-Valera F, Pedrós-Alió C, Moreira D (2001) Unexpected diversity of small eukaryotes in deep-sea Antarctic plankton. Nature 409:603-607

Lovett JS (1963) Chemical and physical characterization of 'nuclear caps' isolated from Blastocladiella zoospores. J Bacteriol 85:1235-1246

Lund JWG (1957) Fungal diseases of plankton algae. In: Horton-Smith C (ed) Biological aspects of the transmission of disease. Oliver and Boyd, Edinburgh

Maclean DJ, Sargent JA, Tommerup IC, Ingram DS (1974) Hypersensitivity as the primary event in resistance to fungal parasites. Nature 249:186-187
Mangot JF, Lepere C, Bouvier C, Debroas D, Domaizon I (2009) Community structure and dynamics of small eukaryotes targeted by new oligonucleotide probes: new insight into the lacustrine microbial food web. Appl Environ Microbiol 75:6373-6381

> Marcogliese DJ (2004) Parasites: small players with crucial roles in the ecological theater. EcoHealth 1:151-164

Marcogliese DJ, Cone DK (1997) Food webs: a plea for parasites. Trends Ecol Evol 12:320-325

May RM, Anderson RM (1979) Population biology of infectious diseases: Part II. Nature 280:455-461

McCallum HI, Kuris A, Harvell CD, Lafferty KD, Smith GW, Porter J (2004) Does terrestrial epidemiology apply to marine systems? Trends Ecol Evol 19:585-591

Meyer FP (1991) Aquaculture disease and health management. J Anim Sci 69:4201-4208

Mitchell SE, Read AF, Little TJ (2004) The effect of a pathogen epidemic on the genetic structure and reproductive strategy of the crustacean Daphnia magna. Ecol Lett $7: 848-858$

Montagnes DJ, Allen J, Brown L, Bulit C and others (2008) Factors controlling the abundance and size distribution of the phototrophic ciliate Myrionecta rubra in open waters of the North Atlantic. J Eukaryot Microbiol 55: $457-465$

Moon-van der Staay SY, De Wachter R, Vaulot D (2001) Oceanic 18S rDNA sequences from picoplankton reveal unsuspected eukaryotic diversity. Nature 409:607-610

> Moreira D, López-García P (2002) The molecular ecology of microbial eukaryotes unveils a hidden world. Trends Microbiol 10:31-38

> Moreira D, López-García P (2003) Are hydrothermal vents oases for parasitic protists? Trends Parasitol 19:556-558

Moreira D, López-García P (2009) Ten reasons to exclude viruses from the tree of life. Nat Rev Microbiol 7: $306-311$

Moss AS, Reddy NS, Dortaj IM, San Francisco MJ (2008) Chemotaxis of the amphibian pathogen Batrachochytrium dendrobatidis and its response to a variety of attractants. Mycologia 100:1-5

> Mouritsen KN, Poulin R (2005) Parasites boosts biodiversity and changes animal community structure by trait-mediated indirect effects. Oikos 108:344-350

Müller U, Sengbusch P (1983) Visualization of aquatic fungi (Chytridiales) parasitizing on algae by means of induced fluorescence. Arch Hydrobiol 97:471-485

> Odum EP (1969) The strategy of ecosystem development. Science 164:262-270

Park MG, Yih W, Coats DW (2004) Parasites and phytoplankton, with special emphasis on dinoflagellate infections. J Eukaryot Microbiol 51:145-155

Paterson RA (1967) Benthic and planktonic Phycomycetes from Northern Michigan. Mycologia 59:405-416

Perkins FO (1993) Infectious diseases of molluscs. In: Couch JA, Fournieand JW (eds) Pathobiology of marine and estuarine organisms. CRC Press, London, p 255-287

Pongratz E (1966) De quelques champignons parasites d'organismes planctoniques du Léman. Aquat Sci 28:104-132

Poulin R, Morand S (2004) Parasite biodiversity. Smithsonian Institution Press, Washington, DC

Pounds JA, Bustamante MR, Coloma LA, Consuegra JA and others (2006) Widespread amphibian extinctions from epidemic disease driven by global warming. Nature 439: 161-167

Powell MJ (1978) Phylogenetic implications of the microbodylipid globule complex in zoosporic fungi. Biosystems 10: $167-180$ 
Raghukumar C (1987) Fungal parasites of marine algae from Mandapam (South India). Dis Aquat Org 3:137-145

Raghukumar S (2002) Ecology of the marine protists, the Labyrinthulomycetes (thraustochytrids and labyrinthulids). Eur J Protistol 38:127-145

Rasconi S, Jobard M, Jouve L, Sime-Ngando T (2009) Use of calcofluor white for detection, identification, and quantification of phytoplanktonic fungal parasites. Appl Environ Microbiol 75:2545-2553

Regoes RR, Nowak MA, Bonhoeffer S (2000) Evolution of virulence in a heterogeneous host population. Evolution 54: $64-71$

Reynolds CS (1973) The seasonal periodicity of planktonic diatoms in a shallow eutrophic lake. Freshw Biol 3:89-110

Reynolds N (1940) Seasonal variations in Staurastrum paradoxum Meyen. New Phytol 39:86-89

Richards TA, Vepritskiy AA, Gouliamova DE, NierzwickiBauer SA (2005) The molecular diversity of freshwater picoeukaryotes from an oligotrophic lake reveals diverse, distinctive and globally dispersed lineages. Environ Microbiol 7:1413-1425

Ricklefs RE, Miller L (1999) Ecology. WH Freeman and Company, New York, NY

Rohwer F, Edwards R (2002) The Phage Proteomic Tree: a genome-based taxonomy for phage. J Bacteriol 184: 4529-4535

Schmidt LM, Mouton L, Nong G, Ebert D, Preston J (2008) Genetic and immunological comparison of the cladoceran parasite Pasteuria ramosa with the nematodeparasite Pasteuria penetrans. Appl Environ Microbiol 74:259-264

Schnepf E, Deichgräber G, Drebes G (1978) Development and ultrastructure of the marine, parasitic oomycete, Lagenisma coscinodisci Drebes (Lagenidiales): formation of the primary zoospores and their release. Protoplasma 94: $263-280$

Sekimoto S, Beakes GW, Gachon CM, Müller DG, Küpper FC, Honda D (2008) The development, ultrastructural cytology, and molecular phylogeny of the basal oomycete Eurychasma dicksonii, infecting the filamentous phaeophyte algae Ectocarpus siliculosus and Pylaiella littoralis. Protist 159:299-318

Sen B (1987a) Fungal parasitism of planktonic algae in Shearwater. I. Occurrence of Zygorhizidium affluens Canter on Asterionella formosa Hass. in relation to the seasonal periodicity of the alga. Arch Hydrobiol 76:101-127

Sen B (1987b) Fungal parasitism of planktonic algae in Shearwater. II. A study of the chytrid parasites of the diatom Fragilaria crotonenis Kitton. Arch Hydrobiol 76: 129-144

Sen B (1988) Fungal parasitism of planktonic algae in Shearwater. IV. Parasitic occurrence of a new chytrid species on the blue-green alga Microcystis aeruginosa Kuetz. emend. Elenkin. Arch Hydrobiol 79:177-184

Shearer CA, Descals E, Kohlmeyer B, Kohlmeyer J and others (2007) Fungal biodiversity in aquatic habitats. Biodivers Conserv 16:49-67

Sherr EB, Sherr BF (1994) Bacterivory and herbivory: key roles of phagotrophic protists in pelagic food webs. Microb Ecol 28:223-235

Sigee DC (2005) Freshwater microbiology. John Wiley \& Sons, Chichester

Sime-Ngando T, Colombet J (2009) Virus et prophages dans

Editorial responsibility: Paul del Giorgio,

Montreal, Canada les écosystèmes aquatiques. Can J Microbiol 55:95-109 (in French with English abstract)

Sindermann CJ (1990) Principal diseases of marine fish and shellfish: diseases of marine fish. Academic Press, London

Smith KF, Acevedo-Whitehouse K, Pedersen AB (2009) The role of infectious diseases in biological conservation. Anim Conserv 12:1-12

Sommer U (1987) Factors controlling the seasonal variation in phytoplankton species composition. A case study for a deep, nutrient rich lake (Lake Constance). Prog Phycol Res 5:122-178

Sparrow FK (1960) Aquatic phycomycetes. University of Michigan Press, Ann Arbor, MI

Sures B (2003) Accumulation of heavy metals by intestinal helminths in fish: an overview and perspective. Parasitology 126:S53-S60

Suttle CA (2007) Marine viruses - major players in the global ecosystem. Nat Rev Microbiol 5:801-812

Trow AH (1899) Observations on the biology and cytology of a new variety of Achlya americana: with plates VIII-X. Ann Bot 13:131-177

Van Donk E (1989) The role of fungal parasites in phytoplankton succession, a review. In: Sommer U (ed) Plankton ecology. Succession in plankton communities. SpringerVerlag, Berlin, p 171-194

Van Donk E, Bruning K (1992) Ecology of aquatic fungi in and on algae. In: Reisser W (ed) Algal symbiosis - plants, animals, fungi, interactions explored. Biopress Limited, Bristol, p 567-592

Van Donk E, Ringelberg J (1983) The effect of fungal parasitism on the succession of diatoms in Lake Maarsseveen I (The Netherlands). Freshw Biol 13:241-251

> Vávra J, Hyliš M, Oborník M, Vossbrinck CR (2005) Microsporidia in aquatic microcrustacea: the copepod microsporidium Marssoniella elegans Lemmermann, 1900 revisited. Folia Parasitol (Praha) 52:163-172

Voyles J, Young S, Berger L, Campbell C and others (2009) Pathogenesis of chytridiomycosis, a cause of catastrophic amphibian declines. Science 326:582-585

> West JA, Klochkova TA, Kim GH, Loiseaux-de Goër S (2006) Olpidiopsis sp., an oomycete from Madagascar that infects Bostrychia and other red algae: host species susceptibility. Phycological Res 54:72-85

> Wommack KE, Colwell RR (2000) Virioplankton: viruses in aquatic ecosystems. Microbiol Mol Biol Rev 64:69-114

Wong MKM, Goh TK, Hodgkiss IJ, Hyde KD and others (1998) Role of fungi in freshwater ecosystems. Biodivers Conserv 7:1187-1206

Wood CL, Byers JE, Cottingham KL, Altman I, Donahue MJ, Blakeslee AM (2007) Parasites alter community structure. Proc Natl Acad Sci USA 104:9335-9339

> Wurzbacher CM, Bärlocher F, Grossart HP (2010) Fungi in lake ecosystems. Aquat Microb Ecol 59:125-149

> Xu K, Song W (2008) Two trichodinid ectoparasites from marine molluscs in the Yellow Sea, off China, with the description of Trichodina caecellae n. sp. (Protozoa: Ciliophora: Peritrichia). Syst Parasitol 69:1-11

> Yao N, Imai S, Tada Y, Nakayashiki H, Tosa Y, Park P, Mayama S (2002) Apoptotic cell death is a common response to pathogen attack in oats. Mol Plant Microbe Interact 15:1000-1007

Submitted: May 19, 2010; Accepted: August 12, 2010

Proofs received from author(s): December 10, 2010 